\title{
Outbreak of Shigella sonnei infection in Norway linked to consumption of fresh basil, October 2011
}

B Guzman-Herrador (BernardoRafael.Guzman.Herrador@fhi.no) ${ }^{1,2}$, L Vold ${ }^{1}$, H Comelli ${ }^{1}$, E MacDonald ${ }^{1}$, B T Heier ${ }^{1}$, A L Wester ${ }^{1}$, T L Stavnes ${ }^{1}$, L Jensvoll ${ }^{3}$, A Lindegård Aanstad ${ }^{4}$, G Severinsen $^{5}$, J Aasgaard Grini ${ }^{6}, \varnothing$ Werner Johansen $^{7}, \mathrm{~K} \mathrm{Cudjoe}^{8}, \mathrm{~K} \mathrm{Nygard}^{1}$

1. Norwegian Institute of Public Health, Oslo, Norway

2. European Programme for Intervention Epidemiology Training (EPIET), European Centre for Disease Prevention and Control $(E C D C)$, Stockholm, Sweden

3. Norwegian Food Safety Authority, Head Office, Oslo, Norway

4. Norwegian Food Safety Authority, District Office. Troms $\varnothing$, Norway

5. Municipality of Tromsø, Norway

6. Norwegian Food Safety Authority, District Office, Østfold, Norway

7. Municipality of Sarpsborg, Østfold, Norway

8. Norwegian Veterinary Institute, Oslo, Norway

Citation style for this article:

Guzman-Herrador B, Vold L, Comelli H, MacDonald E, Heier BT, Wester AL, Stavnes TL, Jensvoll L, Lindegård Aanstad A, Severinsen G, Aasgaard Grini J, Werner Johansen $\emptyset$, Cudjoe K, Nygard K. Outbreak of Shigella sonnei infection in Norway linked to consumption of fresh basil, October 2011.

Euro Surveill. 2011;16(44):pii=20007. Available online: http://www.eurosurveillance.org/ViewArticle.aspx?Articleld=20007

We report a Shigella sonnei outbreak of 46 cases that occurred in Norway during October 2011. Two municipalities were involved. A large cluster (42 cases) was concentrated in north Norway, while a small cluster (4 cases) occurred in the south-east region. Epidemiological evidence and traceback investigations have linked the outbreak to the consumption of imported fresh basil. The product has been withdrawn from the market. No further cases have been reported since 25 October.

\section{Outbreak description}

On 9 October 2011, the Department of Infectious Disease Epidemiology at the Norwegian Institute of Public Health was informed by the Municipal Medical Officer and the Local Food Safety Authority in Troms $\varnothing$ (northern Norway) about an unusually high number of cases of gastrointestinal disease caused by Shigella sonnei.

A delicatessen and catering company located in the centre of Troms $\emptyset$ received several complaints from customers who had fallen ill with gastrointestinal symptoms after having eaten food items from there.

On 14 October, a small cluster of cases who had not been to Troms $\emptyset$ were reported and the outbreak was classified as national.

An outbreak case was defined as a person with gastrointestinal symptoms with laboratory confirmed infection with $S$. sonnei with indistinguishable multiple-locus variable number of tandem repeats analysis (MLVA) profiles in Norway after 1 October 2011.

As of 2 November, 46 cases have been reported (Figure). The outbreak-MLVA profile had not previously been seen in Norway. The cases are distributed in two clusters: 42 cases live in Troms $\varnothing$ in the north of Norway or had been to Troms $\emptyset$ within the incubation period of the disease (up to seven days) [1,2], and four cases live in a municipality (Østfold) in south-east Norway, without any connection to Troms $\emptyset$. None of the cases had travelled outside the country. All cases are adults (aged 19-84 years) and males and females are equally affected. No new cases have been reported since 25 October.

Shigellosis is the third most frequent bacterial gastrointestinal infection reported in Norway. In the last 10 years, between 120 and 190 cases have been registered annually (about 2.5 per 100,000 inhabitants to 4.0 per 100,000 inhabitants). Most of the cases (80$90 \%)$ are travel related. S. sonnei is the most frequent species identified (64\% of all isolates in 2010) [3].

\section{FIGURE}

Laboratory-confirmed outbreak cases due to Shigella sonnei infection, Norway, October $2011(\mathrm{n}=46)$

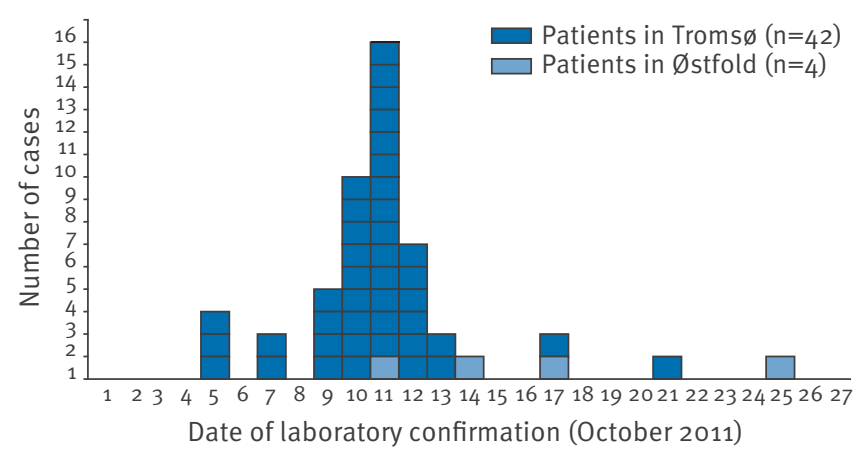


Investigation into the outbreak

On 9 October, the Municipal Medical Officer in Tromsø initiated an investigation in collaboration with the local Food Safety Authority in order to identify the source of the outbreak. The local Food Safety Authority interviewed 38 of the 42 laboratory-confirmed cases in Troms $\emptyset$ : most of them had participated in social events after 30 September where food provided by the catering company in question had been served. Of the 38 cases interviewed, 36 reported to have eaten pesto containing basil. The catering company provided a complete list of all the events for which they had served food from 30 September, which was followed up by the local Food Safety Authority.

One of those events was a baptism ceremony banquet celebrated on 1-2 October. Of the 50 attendees, 10 people became sick with gastrointestinal symptoms. Among the sick, three had laboratory-confirmed infection with $S$. sonnei. In collaboration with the local authorities, the Norwegian Institute of Public Health performed a cohort study among the attendees of the banquet in order to identify risk factors for illness. A link to a web-based questionnaire designed to collect information on demographics, symptoms and food exposures from the menu was sent by email to 42 of the attendees. All of them responded. Preliminary results from the cohort study show that two products, a pesto and a soup, were independently associated with illness. However, only the pesto was delivered by the catering company and could be linked to the other cases occurring in Troms $\emptyset$.

On 11 October, the first case in the small cluster of four cases in a municipality in the south of the country with MLVA profiles indistinguishable identical to the Troms $\varnothing$ profile was identified. Three had been served food containing basil in a specific restaurant.

Traceback investigations of ingredients in the pesto served in Troms $\varnothing$ are still ongoing. The same distributer that provided the fresh basil to the catering company in Troms $\varnothing$ also delivered fresh basil to the restaurant implicated in the second cluster in south-east Norway. The distributor imported this herb from a country outside the European Union and has voluntarily withdrawn it from the market. The National Veterinary Institute analysed samples of pesto and other ingredients from the catering company in Troms $\emptyset$. Samples available for analysis have been negative. An epidemic intelligence information system (EPIS) enquiry has been posted to determine whether other European countries have observed a similar increase in cases infected with S. sonnei. So far, no other countries have reported any recent increase in cases that can be linked to this outbreak.

\section{Conclusion and recommendations}

We report an outbreak of $S$. sonnei in Norway, linked to imported basil used fresh in pesto. The ingestion of very few organisms (10-100) is sufficient to cause infection [4]. Pesto usually contains a substantial amount of basil. Thus, if this herb is contaminated with the bacteria, ingesting very small quantities of pesto can lead to a high risk of getting the infection.

Each year there are a considerable number of outbreaks of shigellosis around the world due to consumption of contaminated food. The contamination of foods with Shigella usually results from contaminated irrigation water, infected food handlers or improper preparation $[5,6]$. The sources of many shigellosis outbreaks have been traced to the ingestion of raw or fresh vegetables [6]. In Norway, for example, iceberg lettuce was incriminated in a S. sonnei outbreak in 1994 [7]. Previous domestic outbreaks of $S$. sonnei infection in Scandinavia have been also linked to imported products [8].

Food handlers with gastrointestinal symptoms should avoid involvement with the preparation, management and transport of food while they are symptomatic in order to prevent spread of the pathogen, and they should also adhere to appropriate hygiene and handwashing routines. Control measures to protect fresh vegetables from air, soil or water contamination should be ensured.

\section{References}

1. Nasjonalt folkehelseinstitutt.Smittevernboka. Manual for communicable diseases control]. Oslo: Nasjonalt folkehelseinstitutt; 2009.

2. Vold L, Heier BT, Comelli H, Nygård K, Kapperud G. Årsreport: Matbårne infeksjoner ogutbruddi 2010 [Annual report:

food-borne diseases and outbreaks in 2010]. Oslo: Nasjonalt folkehelseinstitutt; 2011. Norwegian. Available from: http:// www.fhi.no/dokumenter/cd8fa1273d.pdf

3. Heymann DL. Control of communicable diseases manual. 19th ed. Washington, DC: American Public Health Association: 2008.

4. World Health Organization (WHO). Surface decontamination of fruits and vegetables eaten raw: a review. Geneva: WHO; 1998.

5. Fratamico PM, Bhunia AK, Smith JL. Foodborne pathogens: microbiology and molecular biology. Norwich: Caister Academic Press; September 2005.

6. Begamboula CF, Uyttendaele M, Debevere J. Growth and survival of Shigella sonnei and $S$. flexneri in minimal processed vegetables packed under equilibrium modified atmosphere and stored at $7{ }^{\circ} \mathrm{C}$ and $12{ }^{\circ} \mathrm{C}$. Food Microbiol. 2002;19:529-36.

7. Kapperud G, Rørvik LM, Hasseltvedt V, Høiby EA, Iversen BG, Staveland K, et al. Outbreak of Shigella sonnei infection traced to imported iceberg lettuce. J Clinical Microbiol. 1995; 33(3):609-14.

8. Lewis HC, Ethelberg S, Olsen KE, Nielsen EM, Lisby M, Madsen $S B$, et al. Outbreaks of Shigella sonnei infections in Denmark and Australia linked to consumption of imported raw baby corn., Epidemiol Infect. 2009;137(3):326-34. 